\title{
Factors influencing the infiltration of eosinophils into the mare's endometrium
}

\author{
Roland Kozdrowski ${ }^{1}$, Marcin Nowak ${ }^{2}$, Kornelia Omyła ${ }^{3}$ \\ ${ }^{1}$ Nicolaus Copernicus University, Faculty of Biological and Veterinary Sciences, Toruń, Poland \\ ${ }^{2}$ University of Environmental and Life Sciences, Department of Pathology, \\ Faculty of Veterinary Medicine, Wrocław, Poland \\ ${ }^{3}$ Newcastle Equine Centre, Broadmeadow, NSW, Australia
}

Received October 30, 2020

Accepted February 24, 2021

\begin{abstract}
Factors and consequences related to infiltration of the endometrium by eosinophils in the mare are not fully understood. The aim of the study was to determine the frequency of eosinophilic infiltration into the endometrium in chronically infertile mares and to determine factors conducive to this type of changes. A total of 117 samples of endometrium were collected from infertile mares, 15 samples of endometrium were collected from maiden mares, and all were evaluated histologically. Eosinophilic infiltration of the endometrium was found in 59 mares; in 10 mares, eosinophiles were the predominant cells that had infiltrated the endometrium. The probability of eosinophilic infiltration of the endometrium increases with the age of the mare and with a higher score of endometrial degeneration. The simultaneous infiltration of the endometrium by polymorphonuclear cells and mononuclear cells, in mares being in oestrus, and in mares having fluid in the uterus, also increased the probability. In the group of young mares, eosinophilic infiltration of the endometrium was not detected. Eosinophilic infiltration of the endometrium increases in chronically infertile mares with age and with the presence of other abnormalities observed in the endometrium. We suspect that presence of eosinophils in endometrial tissue together with other abnormalities can be considered as reducing factor for future fertility, however, this hypothesis should be evaluated critically.
\end{abstract}

Horse, infertility, endometritis

Diseases of the endometrium in mares are characterized by inflammation and/or by degeneration. A degenerative process of the endometrium is characterized by periglandular fibrosis and by alternations in the functionality of endometrial glands (Kenney and Doig 1986; Hoffmann et al. 2009). The term endometrosis is frequently used for description of degenerative changes in the mare endometrium, whereas endometritis is characterized by infiltration of the endometrium by leukocytes. Pathogenesis of endometrosis is not fully understood, however, it is suggested that the age of the mare, repeated inflammation of the endometrium, breeding, and parity should be considered as potential aetiological factors (Rebordão et al. 2014). Endometrosis is frequently categorized according to the scheme proposed by Kenney and Doig (1986) into four classes i.e.: I, IIa, IIb and III. However, it is suggested that this scheme, especially if used solely, is insufficient for prediction of the fertility potential in a mare (Schoon and Schoon 2003). Prediction of fertility should also be based on the age of the mare, reproductive history, physical examination, ultrasound findings of the reproductive tract, and results of microbiological and cytological examinations of the endometrium. If necessary, additional histological or immunohistological findings of the endometrium should be taken into consideration for prediction of potential fertility in the mare, e.g., endometrial angiopathies (Schoon and Schoon 2003). Infiltration of the endometrium by polymorphonuclear cells (PMNs) is frequently observed during uterine infections caused by $\beta$-haemolytic streptococci, and infrequently observed when $E$. coli is isolated from the uterus (Riddle et al. 2007;

Address for correspondence:

Roland Kozdrowski,

Faculty of Biological and Veterinary Sciences,

Nicolaus Copernicus University,

Phone +48889134680

Gagarina 11,87-100 Toruń, Poland, 
Nielsen et al. 2010; Overbeck et al. 2011). In contrast to acute endometritis where PMNs are predominant, mononuclear cells are typical for chronic endometritis (Kenney 1978; Kilgenstein et al. 2015). Infiltration of the endometrium both by PMNs and mononuclear cells is frequently observed in chronically infertile mares (Gajos et al. 2015). Eosinophilic infiltration of the endometrium is poorly recognized. Only a few studies have focused on this subject. Infiltration of the mare's endometrium by eosinophils was found during infectious endometritis (Oddsdóttir et al. 2008) and in conditions that enable air aspiration into the uterus, including hysteroscopic examination (Slusher et al. 1984; Schiemann et al. 2001). Increasing number of eosinophils in the endometrium was also observed after breeding and after infusion of seminal plasma into the uterus (Oddsdóttir et al. 2008; Palm et al. 2008). Grimm et al. (2017) claim that infiltration of the endometrium by eosinophils in some cases can be considered as a separate endometrial disease and named endometritis eosinophilica, according to a suggestion given by Schoon et al. (1997).

The aim of the study was to determine the frequency of eosinophilic infiltration into the endometrium in chronically infertile mares, and to determine factors conducive to this type of changes.

\section{Materials and Methods}

The material for this study was collected partially according to a decision approved by II Local Ethics Committee of the Wrocław University of Environmental and Life Sciences, Poland, reference number of approval: 43/2011, and partially the material was collected from commercial patients. This retrospective study was performed on the results obtained from 117 adult warmblood mares aged from 4 to 23 years with a history of infertility. All of these mares had been bred three or more times unsuccessfully; however, previously all these mares had given birth to at least one healthy foal. Additionally, results of breeding soundness examination obtained from 15 maiden mares (young, with no history of breeding) were also analysed.

Before transrectal palpation, external genitalia were examined, and if $80 \%$ of the labia length were below the pelvic brim, the perineal conformation was considered as normal. All mares were examined by transrectal palpation and ultrasonography for genital health and determination of the cycle stage. Some of the data taken under calculation in this study were partially published earlier, namely, the results of microbiological and histological examinations of the mare endometrium (Buczkowska et al. 2014). However, the results presented in this study also contain data collected later. The methodology used for sample collection from the uterus and microbiological examinations of the endometrium have already been described (Buczkowska et al. 2014). Endometrial biopsies were fixed in $10 \%$ formalin and stained with haematoxylin and eosin, and evaluated by light microscopy. Biopsies were evaluated according to Kenney and Doig's (1986) scheme and classified into four classes, i.e. I, IIa, IIb and III. Additionally, infiltrations of the endometrium by PMNs, mononuclear cells, and by eosinophils were recorded (Kenney 1978; Ricketts and Alonso 1991; Kilgenstein et al. 2015). If the mean number of eosinophils was equal or higher than 10 per HPF (high-power field; $\times 400$ magnification) that infiltration was considered significant.

\section{Statistical analysis}

It was checked how the presence of eosinophils in the endomotrium correlates with: a) age of the mare; b) results of histological examination of the endometrium according to categories proposed by Kenny and Doig (1986); c) infiltration of the endometrium by PMNs; d) infiltration of the endometrium by mononuclear cells; e) the stage of the reproductive cycle (oestrus or dioestrus); f) the presence of fluid in the uterus; g) the vulvar conformation, and $\mathrm{h}$ ) uterine infection. For points a-d, due to original data Spearman rank test (rs) was used for evaluation of correlation coefficients, and for points e-h, due to categorical data Chi-square test was used, and then Cramer's V test was used for evaluation of correlation coefficients. The level of significance was set at $P<0.05$. All statistical analyses were performed using StatSoft, Inc. (2014). STATISTICA (data analysis software system), version 12 .

\section{Results}

These results were presented in a preliminary form at the XV Conference of the Polish Society of Veterinary Science, September 22-24, 2016, Lublin, Poland, by the first author of this article (Kozdrowski et al. 2016). Eosinophilic infiltration of the endometrium was found in 59 mares; from that group, in 10 mares the number of eosinophiles per HPF was equal or higher than 10 (Plate III, Figs 1 and 2). Correlations between eosinophilic 


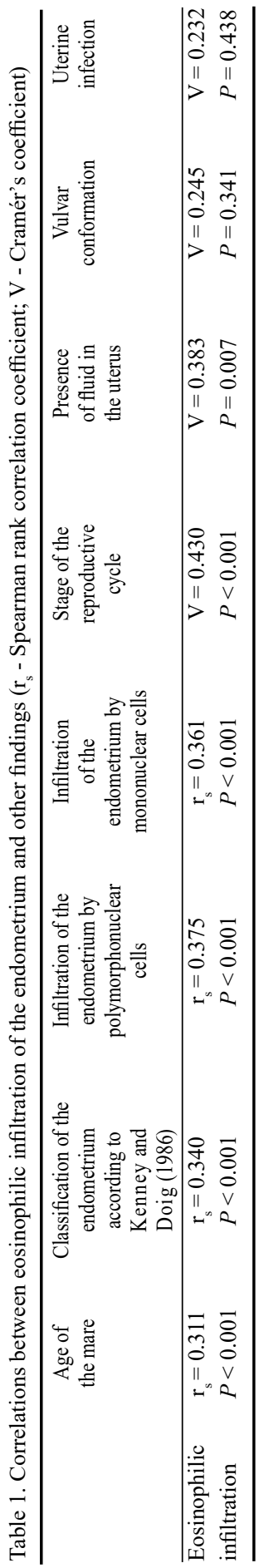

infiltration of the endometrium and other findings are shown in Table 1. According to the results presented in Table 1, probability of eosinophilic infiltration of the endometrium increases with the age of the mare, with the higher score of Kenny and Doig's (1986) category, with the simultaneous infiltration of the endometrium by PMNs and mononuclear cells, in mares being in oestrus, and in mares having fluid in the uterus. It should be mentioned that in the group of maiden mares, eosinophilic infiltration of the endometrium was not detected. No correlation was found between eosinophilic infiltration of the endometrium and vulvar conformation and uterine infection.

\section{Discussion}

It is suggested that the presence of a few eosinophils in the mare's endometrial tissue is a normal component of the local immune system (Palm et al. 2008; Grimm et al. 2017). However, the mechanism(s) responsible for initiating the infiltration of the endometrium by eosinophils and the role played by eosinophils in the endometrial tissue are still not known. In the study conducted by Katkiewicz et al. (2007) on a total of 107 biopsies collected from infertile mares, endometritis eosinophilica was detected in 9 animals but the cause of the marked presence of eosinophils could not be determined. Endometritis eosinophilica may be an idiopathic disease and should be therefore distinguished from eosinophilic infiltration by the criteria described in detail by Grimm et al. (2017). Only the factors which could be connected with eosinophilic presence within the endometrium were analysed in the current study. Palm et al. (2008) found $12 \mathrm{~h}$ after infusion of seminal plasma into the uterus a small increase of eosinophils in the endometrial tissue, however, they did not find an increasing number of eosinophils after treatment with phosphate buffered saline, skim milk or egg yolk extender. It can be indicated that seminal plasma and consequently breeding play a role in triggering eosinophilic infiltration of the endometrium. It should be noted that in our study, eosinophils were never found in the endometrial tissue collected from young mares without a history of breeding. Results obtained in our study indicate that in chronically infertile mares even a few weeks after breeding or artificial insemination, infiltration of the endometrium by eosinophils can be detected. Our results indicate that probability of eosinophilic infiltration of the endometrium is higher during oestrus. It is probably connected with the influence of oestrogens; in rats treated with oestrogens, a rapid eosinophilic infiltration into endometrium was observed (Tchernitchin et al. 1976). Grimm et al. (2017) found the highest numbers of eosinophils in the mare's endometrium during the mid and late interoestrus. Kenney (1978) noticed that eosinophils seem to also occur more frequently in an inflamed uterus during oestrus. 
It has been shown that hysteroscopic examination, or more precisely insufflations of the uterus with air, triggered infiltration of the endometrium by eosinophils (Schiemann et al. 2001). Elevated number of eosinophils was still observed during the next oestrus after hysteroscopic examination, however, a downward trend was observed. Aspiration of the air is facilitated by abnormal perineal conformation, however, in our study we did not find a correlation between abnormal perineal conformation and eosinophilic infiltration of the endometrium. Similarly, in a group of chronically infertile Icelandic mares which were characterized by normal perineal conformation, infiltration of the endometrium by eosinophils was found (Sikora et al. 2016). The lack of correlation between infiltration of the endometrium by eosinophils and uterine infection corresponds with the opinion of other authors (Schiemann et al. 2001). This is in contrast to a study which indicated that infiltration of the endometrium by eosinophils can be more visible in response to uterine infection than to breeding (Oddsdóttir et al. 2008).

Similarly to our results, in the study of Palm et al. (2008) an increased number of eosinophils was accompanied by an increased number of PMNs. Moreover, Grimm et al. (2017) similarly described a positive relationship between infiltration of the endometrium by eosinophils and endometrosis, as well as with infiltration of the endometrium by PMNs, indicating an association between eosinophilic infiltration and presence of PMNs. They also suggest a possible role of mast cells in the pathogenesis of endometritis eosinophilica. It was shown in women that presence of eosinophils in the endometrial tissue is frequently correlated with presence of plasma cells, thus indicating chronic endometritis (Adegboyega et al. 2010). It seems that eosinophilic infiltration of the endometrium in mares depends on infiltration of the endometrium by PMNs and lymphocytes, and also on endometrosis, but a direct factor responsible for that process is still unknown.

Based on the results obtained in this work it could be said that the probability of eosinophilic infiltration of the endometrium increases in chronically infertile mares with the age and with the presence of another abnormalities observed in the endometrium in histological examination. We suspect that presence of eosinophils in the endometrial tissue together with other abnormalities can be considered as a reducing factor for future fertility, however, this hypothesis should be evaluated critically.

\section{Acknowledgements}

The authors thank Justyna Buczkowska, Monika Sikora and Katarzyna Wojtysiak for help with material collection.

\section{References}

Adegboyega PA, Pei Y, McLarty J 2010: Relationship between eosinophils and chronic endometritis. Hum Pathol 41: $33-37$

Buczkowska J, Kozdrowski R, Nowak M, Raś A, Staroniewicz Z, Siemieniuch MJ 2014: Comparison of the biopsy and cytobrush techniques for diagnosis of subclinical endometritis in mares. Reprod Biol Endoc 12: 27

Gajos K, Kozdrowski R, Nowak M, Siemieniuch MJ 2015: Altered secretion of selected arachidonic acid metabolites during subclinical endometritis relative to estrous cycle stage and grade of fibrosis in mares. Theriogenology 84: 457-466

Grimm AL, Schoon HA, Schöniger S 2017: Histopathological features of endometritis eosinophilica in mares. Histol Histopathol 32: 1161-1173

Hoffmann C, Ellenberger C, Mattos RC, Aupperle H, Dhein S, Stief B, Schoon HA 2009: The equine endometrosis: new insights into the pathogenesis. Anim Reprod Sci 111: 261-278

Katkiewicz M, Witkowski M, Zając S 2007: Ocena mikroskopowa wycinków błony śluzowej macicy klaczy obraz struktury prawidłowej i chorobowej. Med Weter 63: 463-466

Kenney RM 1978: Cyclic and pathologic changes of the mare endometrium as detected by biopsy, with a note on early embryonic death. J Am Vet Med Assoc 172: 241-262

Kenney RM, Doig PA 1986: Equine endometrial biopsy. In Morrow DA(Ed.): Current Therapy in Theriogenology. Saunders, Philadelphia, USA, pp. 723-729

Kilgenstein HJ, Schöniger S, Schoon D, Schoon HA 2015: Microscopic examination of endometrial biopsies of retired sports mares: An explanation for the clinically observed subfertility? Res Vet Sci 99: 171-179 
Kozdrowski R, Sikora M, Wojtysiak K, Nowak M 2016: Eozynofilowe zapalenie macicy klaczy (in Polish, Endometritis eosinophilica in the mare). XV Congress PTNW, September 22-24, 2016, Lublin, Poland, p. 268

Nielsen JM, Troedsson MH, Pedersen MR, Lehen-Jensen H 2010: Diagnosis of endometritis in the mare based on bacteriological and cytological examinations of the endometrium. Comparison of results obtained by swabs and biopsies. J Eqiune Vet Sci 30: 27-30

Oddsdóttir C, Smith S, Watson ED 2008: Leukocyte distribution in the equine endometrium as a response to acute induced endometritis. Pferdeheilkunde 24: 66-70

Overbeck W, Witte TS, Heuwieser W 2011: Comparison of three diagnostic methods to identify subclinical endometritis in mares. Theriogenology 75: 1311-1318

Palm FM, Walter I, Budik S, Kolodziejek J, Nowotny N, Aurich C 2008: Influence of different semen extender and seminal plasma on PMN migration and on expression of IL-1 $\beta$, IL-6, TNF- $\alpha$ and COX-2 mRNA in the equine endometrium. Theriogenology 70: $843-851$

Rebordão MR, Galvao A, Szóstek A, Amaral A, Mateus L, Skarżyński DJ, Ferreira-Dias G 2014: Physiopathologic mechanisms involved in mare endometrosis. Reprod Dom Anim 49: 82-87

Ricketts SW, Alonso S 1991: The effect of age and parity on the development of equine chronic endometrial disease. Equine Vet J 23: 189-192

Riddle WT, LeBlanc MM, Stromberg AJ 2007: Relationships between uterine culture, cytology and pregnancy rates in a Thoroughbred practice. Theriogenology 68: 395-402

Schiemann V, Bartmann CP, Kirpal G, Reiswitz A, Schoon HA, Klug E 2001: Diagnostic hysteroscopy in the mare - uterine contamination and endometrial reaction. Pferdeheilkunde 17: 557-564

Schoon HA, Schoon D, Klug E 1997: Die Endometriumbiopsie bei der Stute im klinisch-gynäkologischen Kontext. Pferdeheilkunde 13: 453-564

Schoon HA, Schoon D 2003: The Category I mare (Kenney and Doig 1986): expected foaling rate 80-90\% - fact or fiction? Pferdeheilkunde 19: 698-701

Sikora M, Król J, Nowak M, Stefaniak T, Aubertsson G, Kozdrowski R 2016: The usefulness of uterine lavage and acute phase protein levels as a diagnostic tool for subclinical endometritis in Icelandic mares. Acta Vet Scand 58: 50

Slusher SH, Freeman KP, Roszel JF 1984: Eosinophils in equine uterine cytology and histology specimens. J Am Vet Med Assoc 184: 665-670

Tchernitchin X, Tchernitchin A, Galand P 1976: Dynamics of eosinophils in the uterus after oestrogen administration. Differentation 5: 151-154 
Plate III

Kozdrowski R. et al.: Factors ... pp. 63-67

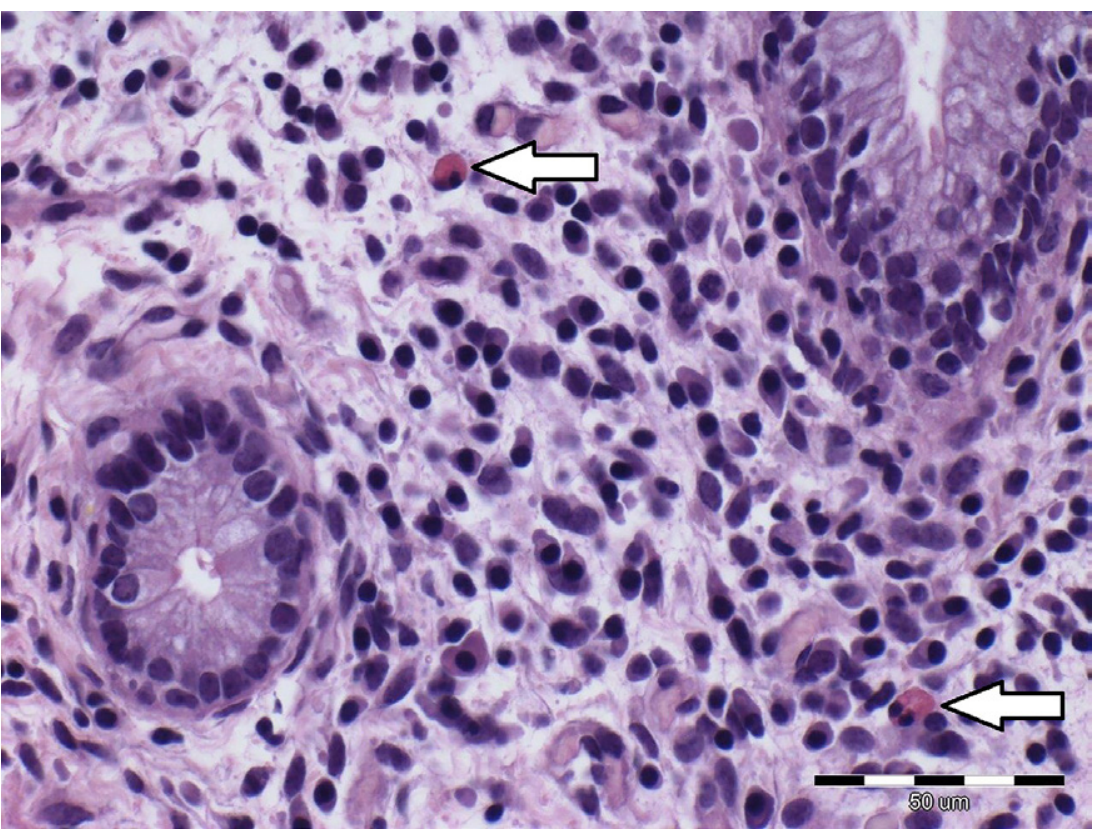

Fig. 1. Slight infiltration of the endometrium by eosinophilic cells. In addition, numerous mononuclear cells surrounding the glands are visible. Arrows indicate eosinophils. $\times 400$ magnification.

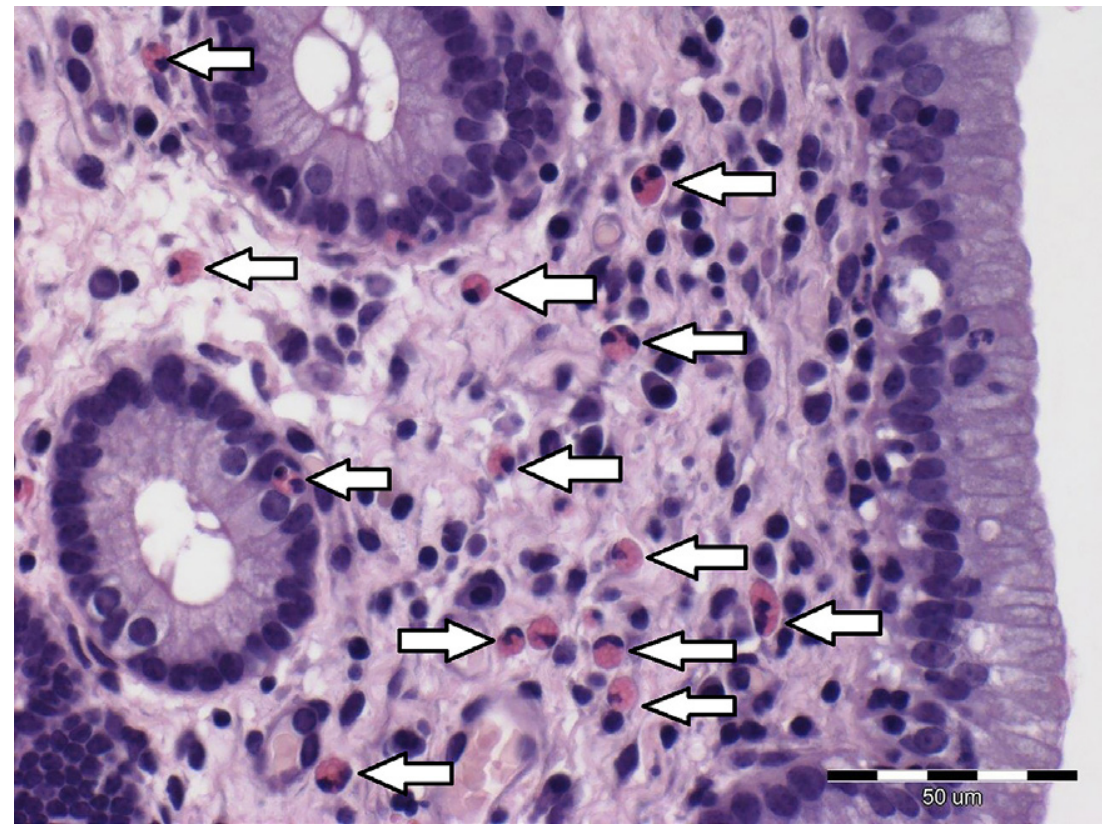

Fig. 2. Significant infiltration of the endometrium by eosinophilic cells. In addition, mononuclear cells surrounding the glands and single neutrophils located under the epithelium are visible. Arrows indicate eosinophils. $\times 400$ magnification. 